\title{
Purification and Properties of Xanthine Oxidase from Enterobacter cloacae
}

\author{
Yozo MACHIDA and Toru NAKANISHI \\ Tokyo Research Laboratory, Kyowa Hakko Kogyo Co., Ltd., \\ Machida-shi, Tokyo 194, Japan \\ Received July 31, 1980
}

\begin{abstract}
Enterobacter cloacae KY 3074 grown in a medium containing xanthine, hypoxanthine, guanine, or their nucleosides and nucleotides produced xanthine oxidase. The purified enzyme preparation showed a major protein band and a few minor bands in acrylamide gel electrophoresis. Molecular oxygen was the most effective electron acceptor. Ferricyanide and 2,6-dichlorophenolindophenol also served as electron acceptors, but NAD and NADP did not. Xanthine and hypoxanthine were good substrates, and guanine was also an effective substrate. The activity was inhibited by $\mathrm{Ag}^{2+}, \mathrm{Cu}^{2+}, \mathrm{PCMB}$, and ascorbate. The spectrum of the Enterobacter enzyme resembled that of some known xanthine oxidizing enzymes, and this suggests a similarity in the prosthetic groups of these enzymes. The molecular weight of the native enzyme and subunit was 128,000 and 69,000 , respectively.
\end{abstract}

Xanthine-oxidizing enzymes can utilize various electron acceptors for the oxidation of hypoxanthine and xanthine to uric acid. Most of the xanthine-oxidizing enzymes from microorganisms are xanthine dehydrogenases (EC 1.2.1.37) ${ }^{\left.1 \sim^{4}\right)}$ and show the highest activity in the presence of electron acceptor as ferricyanide, 2,6-dichlorophenolindophenol, dyes, or ferredoxin. However, some microbial xanthine dehydrogenases use NAD as the most effective electron acceptor..$^{5 \sim 8}$

Xanthine oxidase (EC 1.2.3.2) distributes among mammalian milks, but in microorganisms the enzyme activity is weak as compared with xanthine dehydrogenase activity.

Woolfolk and Downard reported on the bacterial xanthine oxidase from Arthrobacter S-2. ${ }^{9)}$ With molecular oxygen, their oxidase oxidized xanthine in a rate of only $64 \%$ of that observed with ferricyanide as the electron acceptor. Therefore, molecular oxygen does not seem to be the most effective electron acceptor for the enzyme.

We investigated xanthine oxidase (XOD) activities of the microorganisms grown in a medium containing xanthine, and found Enterobacter cloacae KY3074 to be prominent in the enzyme activity. The Enterobacter xanthine oxidase gave the highest activity with molecular oxygen.
This paper reports on the purification and some properties of xanthine oxidase of $E$. cloacae KY3074.

\section{MATERIALS AND METHODS}

Cultivation of cells and preparation of crude enzyme extracts. The microorganisms examined were cultured aerobically in the medium containing $0.2 \%$ xanthine, $0.1 \%$ peptone, $0.5 \%$ corn steep liquor, $0.05 \%$ $\mathrm{KH}_{2} \mathrm{PO}_{4}, 0.1 \% \mathrm{~K}_{2} \mathrm{HPO}_{4}$, and $0.05 \% \mathrm{MgSO}_{4} \cdot 7 \mathrm{H}_{2} \mathrm{O}$ at $\mathrm{pH} 7.2$ for $72 \mathrm{hr}$ at $30^{\circ} \mathrm{C}$. The grown cells were collected by centrifugation, suspended in $50 \mathrm{~mm}$ Tris $\cdot \mathrm{HCl}$

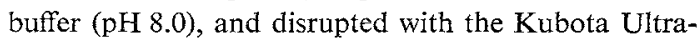
sonic Generator (KMS-250) for $10 \mathrm{~min}$. The disrupted mixture was centrifuged and the supernatant was used as a crude enzyme extract.

Enzyme assay. Xanthine oxidase was assayed by the following two methods: Assay method I was performed by measuring absorbance at $283 \mathrm{~nm}$ due to uric acid produced by oxidation of xanthine. The standard assay mixture was $3 \mathrm{ml}$ as a total volume and contained $100 \mu \mathrm{mol}$ Tris $\cdot \mathrm{HCl}$ buffer $(\mathrm{pH} 7.3), 2 \mu \mathrm{mol}$ xanthine and enzyme. The reaction was performed at $37^{\circ} \mathrm{C}$ for $10 \mathrm{~min}$, and was stopped by the addition of $12 \mathrm{ml}$ of $0.2 \mathrm{~N} \mathrm{HCl}$, and the absorbance was measured at $283 \mathrm{~nm}$. The reference value was provided by adding $\mathrm{HCl}$ prior to the addition of enzyme and measured as above. The molecular extinction coefficient of uric acid under the condition was $1.238 \times 10^{4} .{ }^{10}$ ) One unit of enzyme activity was defined as the enzyme amount that produced $1 \mu \mathrm{mol}$ uric acid per min at pH 7.3 and $37^{\circ} \mathrm{C}$. Assay method II was done by the method of Allain et al. ${ }^{11}$ The standard assay mixture 
contained $100 \mu \mathrm{mol}$ Tris $\cdot \mathrm{HCl}$ buffer $(\mathrm{pH} 7.3$ ), $2 \mu \mathrm{mol}$ xanthine, $5 \mu \mathrm{mol} 4$-aminoantipyrine, $5 \mu \mathrm{mol}$ phenol, 2.5 units peroxidase, and enzyme in total volume of $3 \mathrm{ml}$. The reaction was performed at $37^{\circ} \mathrm{C}$ for $10 \mathrm{~min}$, and the production of $\mathrm{H}_{2} \mathrm{O}_{2}$ by oxidation of xanthine was measured in absorbance at $500 \mathrm{~nm}$. The molecular extinction coefficient of $6.3 \times 10^{3}$ at $\mathrm{pH} 7.3$ was used. One unit of enzyme activity was defined as $1 \mu \mathrm{mol}$ $\mathrm{H}_{2} \mathrm{O}_{2}$ production from xanthine per min at $\mathrm{pH} 7.3$ and $37^{\circ} \mathrm{C}$.

Protein assay. The amount of protein was determined by the method of Lowry et al. ${ }^{12}$ using bovine serum albumin as a standard. In chromatographic procedures, the absorbance at $280 \mathrm{~nm}$ was measured.

Electrophoresis. Analytical disc electrophoresis was carried out according to the method by Davis ${ }^{13}$ ) using columns of $7.5 \%$ polyacrylamide gel with the $\mathrm{pH} 8.3$ buffer system. Protein samples were loaded on the columns and a constant current of $4 \mathrm{~mA}$ per column was applied at room temperature. The gel was stained for protein with Amido Black 10B and for the enzymatically active zone by incubating it in the standard assay mixture of the enzyme assay method II.

SDS-Electrophoresis. SDS-electrophoresis was performed by a modification of Weber and Osborn ${ }^{14}$ with columns of $10 \%$ polyacrylamide gel containing $0.1 \%$ SDS. Electrophoresis was performed at a constant current of $8 \mathrm{~mA}$ per column at room temperature. Cytochrome $c$ (molecular weight, 12,400), myoglobin $(17,800)$, chymotripsinogen $(25,000)$, ovalbumin $(45,000)$, bovine serum albumin $(68,000)$, and phosphorylase $b$ $(92,500)$ were used as standards.

Determination of molecular weight. Gel filtration was performed according to the method of Andrews ${ }^{15}$ ) with a column of Sephadex G-200 $(2.6 \times 75 \mathrm{~cm})$ equilibrated with the $50 \mathrm{~mm}$ Tris $\cdot \mathrm{HCl}$ buffer ( $\mathrm{pH} 8.0$ ) containing $0.1 \mathrm{M} \mathrm{KCl}$. Elution was performed with the same buffer, and eluates were collected in $3 \mathrm{~g}$ fractions. Ovalbumin $(45,000)$, bovine serum albumin $(68,000)$ and alcohol dehydrogenase $(148,000)$ were used as standards.

Isoelectric focusing. Isoelectric focusing was carried out according to Vesterberg and Svensson. ${ }^{16)}$ The enzyme protein was applied to a column $(110 \mathrm{ml})$ of carrier ampholite with a pH range of 3.5 to 5.0 . A constant potential of $900 \mathrm{~V}$ was applied to the column at $5^{\circ} \mathrm{C}$ for $22 \mathrm{hr}$ and the column was fractionated into $2 \mathrm{~g}$ fractions.

Chemicals. Most of the nucleotide-related compounds were obtained from Kyowa Hakko Kogyo Co. Peroxidase, purine, uric acid, xanthosine and 4-aminoantipyrine were obtained from Sigma, Nakarai Chemicals, Koso Chemicals Co., P-L Biochemicals, and
Wako Pure Chemicals Industries, respectively. Other compounds were of reagent grade and from commercial sources.

\section{RESULTS}

\section{Xanthine oxidase activity in various micro- organisms}

Brevibacterium imperiale, Brevibacterium fuscum, Corynebacterium rathayi, Pseudomonas gelidicola, and Sarcina aurantiaca were capable of growing with a medium containing xanthine among many bacteria, yeasts, actinomycetes, and molds. Of these bacteria, xanthine oxidase activity was observed in only Enterobacter cloacae KY3074 by using assay method. II.

The following experiments were made with Enterobacter cloacae KY3074.

\section{Induction of xanthine oxidase}

The enzyme activity of the cells grown in media containing various purines, nucleosides, or nucleotides was compared (Table I). This enzyme activity was found in the cells grown in media containing guanine, hypoxanthine, xanthine, or their nucleosides and nucleotides.

\section{Table I. Xanthine Oxidase Activity of the Cells Grown on Various Purines}

Each substrate was added instead of xanthine to the medium described in Materials and Methods at concentration of $20 \mathrm{mM}$. Enterobacter cloacae KY3074 was cultured for 2 days, and cells were collected by centrifugation. Xanthine oxidase activity was indicated with the activity in one $\mathrm{ml}$ of cultured fluid.

\begin{tabular}{lc}
\hline \multicolumn{1}{c}{ Purine base } & $\begin{array}{c}\text { XOD activity } \\
\text { (munits/ml) }\end{array}$ \\
\hline None & 12 \\
Purine & 23 \\
Adenine & 11 \\
Guanine & 81 \\
Xanthine & 75 \\
Hypoxanthine & 177 \\
Adenosine & 27 \\
Guanosine & 191 \\
Xanthosine & 113 \\
Inosine & 113 \\
GMP* & 172 \\
IMP* & 84 \\
Uric acid & 38 \\
\hline
\end{tabular}

GMP*, guanosine-5'-monophosphate;

IMP*, inosine-5'-monophosphate. 


\section{Purification of the enzyme}

Unless otherwise stated, all purification procedures were carried out at about $5^{\circ} \mathrm{C}$ in $50 \mathrm{~mm}$ Tris $\cdot \mathrm{HCl}$ buffer ( $\mathrm{pH} 8.0)$ and centrifugation was carried out at $10,000 \times g$ for $15 \mathrm{~min}$.

The grown cells (wet weight $55 \mathrm{~g}$ ) were harvested by centrifugation, suspended in the buffer and disrupted with Dyno Mill. Extracts were centrifuged and the supernatant solution was used as crude extract.

Solid ammonium sulfate was added to the crude extract and precipitates from between 0.3 and 0.65 saturations were collected by centrifugation. The precipitates were dissolved in the buffer and dialyzed. A precipitate formed during dialysis was removed by centrifugation.

The supernatant solution was loaded on a column of DEAE-cellulose (1 liter column) previously equilibrated with the buffer, and the column was washed with the buffer and then the enzyme was eluted with an increasing linear gradient concentration from 0 to $0.6 \mathrm{M}$ $\mathrm{NaCl}$ in the buffer. The active fractions were combined and precipitated at 0.8 saturation of ammonium sulfate.

The precipitates were dissolved in the buffer and subjected to a column of Sepharose $4 \mathrm{~B}$ (1 liter column) equilibrated with the buffer, and the column was eluted with the buffer.

The active fractions were collected and subjected to gel filtration on a column of Sephadex G-150 (1 liter column). The column was eluted with the buffer, active fractions were collected and then loaded on a column of DEAESephadex A-50 (500 ml column) previously equilibrated with the buffer containing $0.1 \mathrm{M}$ $\mathrm{NaCl}$. The column was washed with the same buffer and then the enzyme was eluted with an increasing linear gradient concentration from 0.1 to $0.6 \mathrm{M} \mathrm{NaCl}$ in the buffer. The active fractions were collected and dialyzed against 10 times volume of $5 \mathrm{~mm}$ sodium phosphate buffer ( $\mathrm{pH}$ 6.8) overnight.

The dialyzed solution was loaded on a column of hydroxyapatite (100 ml column) equilibrated with $5 \mathrm{~mm}$ phosphate buffer (pH 6.8) and the enzyme was eluted with a linear gradient of buffer concentration from 5 to $80 \mathrm{~mm}$ phosphate buffer (pH 6.8). The active fractions were combined and dialyzed against $50 \mathrm{~mm}$ Tris $\cdot \mathrm{HCl}$ buffer $(\mathrm{pH} \mathrm{8.0)}$ and the dialyzed solution was used as the purified enzyme. The results of the purification of the enzyme are summarized in Table II. The enzyme was purified about 400 fold from the crude extract in a yield of $14 \%$.

Table II. Purification of Xanthine Oxidase FROM Enterobacter cloacae

\begin{tabular}{lrrrc}
\hline \multicolumn{1}{c}{ Step } & $\begin{array}{c}\text { Total } \\
\text { unit } \\
(\mathrm{U})\end{array}$ & $\begin{array}{r}\text { Total } \\
\text { protein } \\
(\mathrm{mg})\end{array}$ & $\begin{array}{c}\text { Sp. } \\
\text { activity } \\
(\mathrm{U} / \mathrm{mg})\end{array}$ & $\begin{array}{c}\text { Recovery } \\
(\%)\end{array}$ \\
\hline $\begin{array}{l}\text { Crude extract } \\
\text { Ammonium sulfate }\end{array}$ & 4800 & 128880 & 0.037 & 100 \\
$\quad(30 \sim 65 \%$ sat $)$ & 2381 & 32500 & 0.073 & 50 \\
DEAE-cellulose & 1589 & 1268 & 1.25 & 33 \\
Sepharose 4B & 1258 & 678 & 1.85 & 26 \\
Sephadex G-150 & 1176 & 469 & 2.51 & 24 \\
DEAE-Sephadex & & & & \\
$\quad$ A-50 & 874 & 72.6 & 12.0 & 18 \\
Hydroxyapatite & 662 & 43.6 & 15.2 & 14 \\
\hline
\end{tabular}

\section{Homogeneity of the enzyme preparation}

As shown in Fig. 1, the purified enzyme gave main protein band and a few minor protein bands and an activity band with a mobility identical to that of the main protein band in analytical disc electrophoresis.

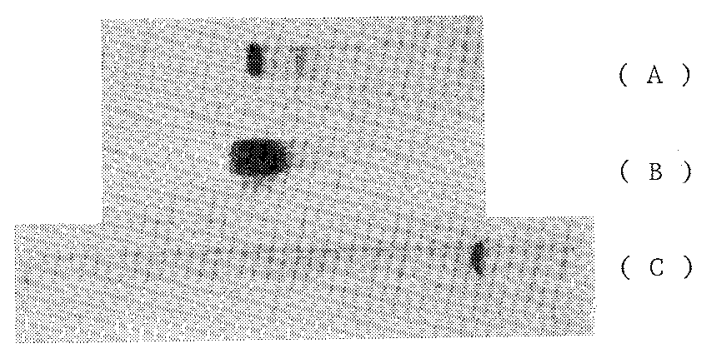

FIG. 1. Polyacrylamide Gel Electrophoresis of the Purified Xanthine Oxidase.

A, stained with Amine Black 10B; B, stained for enzyme activity as described in MATERIALS AND MeTHODS; C, SDS-electrophoresis.

\section{Molecular weight and subunit structure}

Gel filtration method with Sephadex G-200 was used to estimate the molecular weight of the purified enzyme. The molecular weight was calculated to be about 128,000 (Fig. 2). 


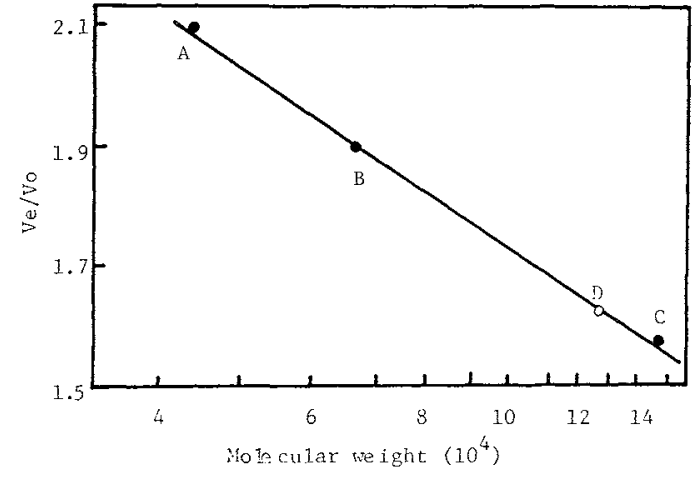

FIG. 2. Determination of Molecular Weight of Xanthine Oxidase.

A, ovalbumin; B, bovine serum albumin; $C$, alcohol dehydrogenase; $D$, xanthine oxidase.

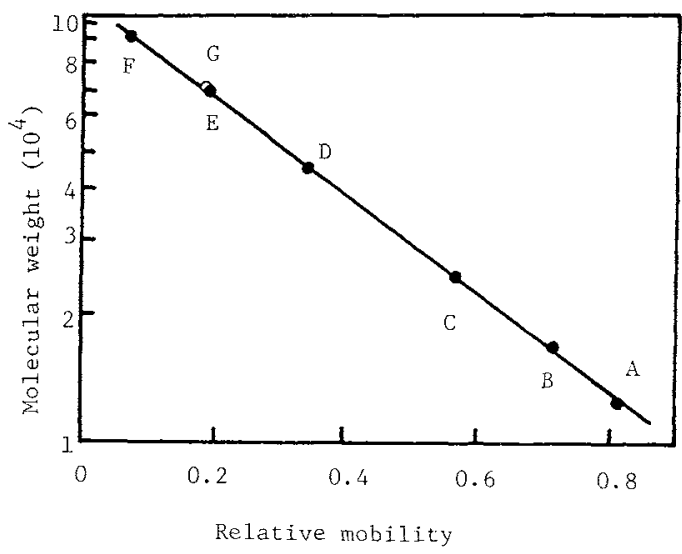

FIG. 3. Determination of Molecular Weight of Xanthine Oxidase Subunit.

A, cytochrome $c ; B$, myoglobin; C, chymotripsinogen $D$, ovalbumin; E, bovine serum albumin; $F$, phosphorylase $b ; \mathrm{G}$, xanthine oxidase.

In SDS-electrophoresis, a single protein band (Fig. 1) corresponding to a molecular weight of 69,000 was obtained, as shown in Fig. 3. It is suggested that the enzyme consists of two identical subunits.

\section{Isoelectric point}

The isoelectric point of the enzyme was found to be at $\mathrm{pH} 3.8$ by isoelectric focusing.

\section{Spectral characteristics}

Absorption spectra of the oxidized and hydrosulfite-reduced forms of the enzyme are shown in Fig. 4. The oxidized enzyme ex-

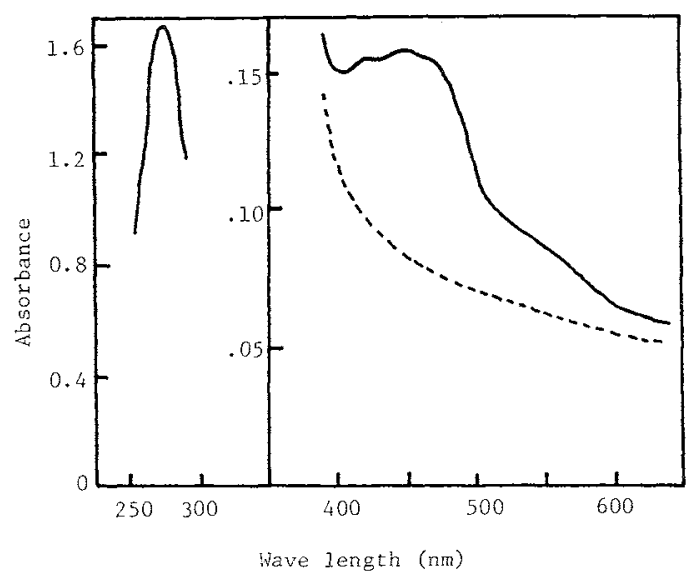

FIG. 4. Absorption Spectra of the Purified Xanthine Oxidase.

-_, oxidized form; --.-.-, hydrosulfite-reduced form.

hibited absorption maxima at 280 and $450 \mathrm{~nm}$, shoulder at 425 and $473 \mathrm{~nm}$. Reduction of the enzyme with sodium hydrosulfite resulted in elimination of the absorption maximum at $450 \mathrm{~nm}$. The spectral characteristics suggest that the enzyme is an iron-containing flavoprotein.

Effect of $p H$, temperature, and various compounds of the activity

The effect of $\mathrm{pH}$ and temperature on the activity was studied with xanthine as substrate. The enzyme was found to be most active at pH 7.1 and 35 to $45^{\circ} \mathrm{C}$ (Fig. 5).

The effect of various metal ions and other compounds on the activity was presented in Tables III and IV. The activity was inhibited

\section{Table III. Effect of Metal Ions ON THE ENZYME ACTIVITY}

Reactions were performed with assay method I involving 50 munits of XOD and metal ions of indicated concentration.

\begin{tabular}{lcc}
\hline Metal ion & $\begin{array}{c}\text { Concentration } \\
(\mathrm{mm})\end{array}$ & $\begin{array}{c}\text { Inhibition } \\
(\%)\end{array}$ \\
\hline $\mathrm{MgSO}_{4}$ & 1 & 0 \\
$\mathrm{MnCl}_{2}$ & 1 & 0 \\
$\mathrm{CoSO}_{4}$ & 1 & 21.3 \\
$\mathrm{CuCl}_{2}$ & 0.01 & 79.6 \\
$\mathrm{FeCl}_{3}$ & 1 & 44.7 \\
$\mathrm{AgNO}_{3}$ & 0.001 & 54.8 \\
\hline
\end{tabular}




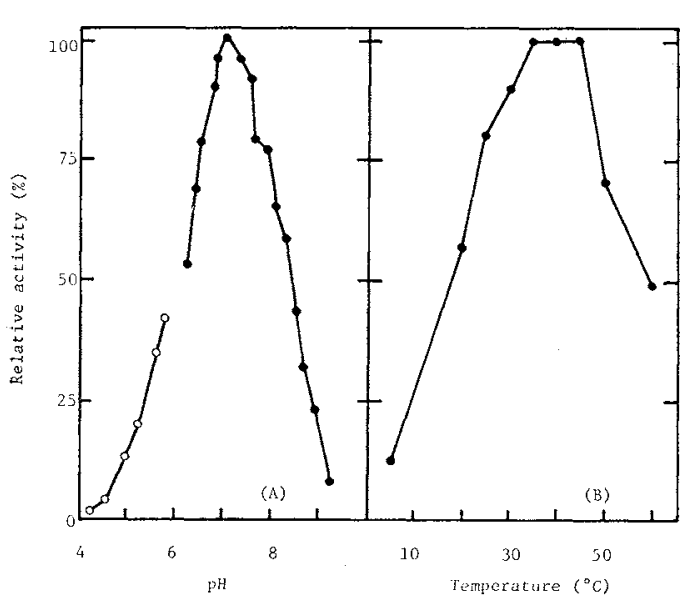

Fig. 5. Effect of $\mathrm{pH}$ and Temperature on the Activity of Xanthine Oxidase.

(A) Activity was measured with assay method I except that reaction $\mathrm{pH}$ was varied. The reaction mixture contained $50 \mathrm{~m}$ units of XOD, $2 \mu \mathrm{mol}$ xanthine and various buffers. Following buffers were used: 0 , acetate; $\bullet$, potassium phosphate-sodium borate.

(B) Activity was measured with assay method I except that reaction temperature was varied. The reaction mixture contained $50 \mathrm{~m}$ units of XOD, $2 \mu \mathrm{mol}$ xanthine and $100 \mu \mathrm{mol}$ borate buffer (pH 7.0).

Table IV. Effect of Various Compounds ON THE ENZYME ACTIVITY

Reactions were performed with assay method I involving 50 munits of XOD and additives of concentrations indicated.

\begin{tabular}{lcc}
\hline Compound & $\begin{array}{c}\text { Concentration } \\
(\mathrm{mM})\end{array}$ & $\begin{array}{c}\text { Inhibition } \\
(\%)\end{array}$ \\
\hline EDTA & 1 & 0 \\
$\mathrm{NaN}_{3}$ & 1 & 0 \\
$\alpha, \alpha^{\prime}$-Dipyridyl & 1 & 5.2 \\
$o$-Phenanthroline & 1 & 7.2 \\
8-Hydroxyquinoline & 1 & 2.1 \\
$\mathrm{H}_{2} \mathrm{O}_{2}$ & 1 & 43.3 \\
$\mathrm{KCN}$ & 1 & 2.1 \\
Iodoacetic acid & 1 & 3.1 \\
PCMB* & 0.01 & 34.7 \\
L-Ascorbic acid & 0.01 & 61.7 \\
\hline
\end{tabular}

PCMB*, p-chloromercuribenzoate.

by $\mathrm{Ag}^{+}, \mathrm{Cu}^{2+}, \mathrm{Fe}^{3+}, \mathrm{Co}^{2+}, \mathrm{H}_{2} \mathrm{O}_{2}, \mathrm{PCMB}$, and ascorbate.

\section{Effect of $p H$ and temperature on the stability}

The enzyme was found to be stable at $\mathrm{pH}$ range between 6.2 and 6.8 , when kept at $60^{\circ} \mathrm{C}$ for $30 \mathrm{~min}$. The activity remained $100 \%$ at temperatures below $50^{\circ} \mathrm{C}$ for $30 \mathrm{~min}$ and was lost completely at temperatures above $70^{\circ} \mathrm{C}$.

\section{Substrate specificity}

The compounds listed in Table V were examined by xanthine oxidase assay method II. Xanthine, hypoxanthine, 2-hydroxypurine, guanine, and purine was oxidized at considerable rates, and the activity was highest with xanthine. Benzaldehyde and 6-mercaptopurine were oxidized slowly, whereas adenine, uric acid, acetaldehyde, and $\mathrm{NADH}$ were not oxidized.

\section{Table V. Substrate Specificity}

Enzyme reactions were performed with assay method II involved 50 munits of XOD and $5 \mu \mathrm{mol}$ of the substrate listed. The enzyme did not oxidize uric acid, purine nucleosides, theophylline, theobromine, and acetaldehyde.

\begin{tabular}{lc}
\hline Substrate & $\begin{array}{c}\text { Relative activity } \\
(\%)\end{array}$ \\
\hline Purine & 23.3 \\
Hypoxanthine & 92.3 \\
2-Hydroxypurine & 88.5 \\
6-Mercaptopurine & 4.4 \\
Xanthine & 100 \\
Adenine & 0 \\
Guanine & 53.3 \\
Benzaldehyde & 9.8 \\
NADH & 0 \\
\hline
\end{tabular}

TABLE VI. ACTIVITIES WITH Various ELECTRON ACCEPTORS

Enzyme reactions were performed anaerobically in mixture $(2.0 \mathrm{ml})$ containing $73 \mu \mathrm{mol}$ of Tris $\cdot \mathrm{HCl}$

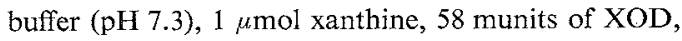
and one of the compounds listed at the indicated concentration at $37^{\circ} \mathrm{C}$, and activities were determined by measuring absorbance changes at the wavelengths indicated between 15 and 75 seconds.

\begin{tabular}{lccc}
\hline Electron acceptor & $\begin{array}{c}\text { Concen- } \\
\text { tration } \\
\text { (mM) }\end{array}$ & $\begin{array}{c}\text { Wavelength } \\
\text { observed } \\
(\mathrm{nm})\end{array}$ & $\begin{array}{c}\text { Relative } \\
\text { activity } \\
(\%)\end{array}$ \\
\hline $\mathrm{O}_{2}$ & dissolved & 295 & 100 \\
$\mathrm{NAD}$ & 0.1 & 340 & 0 \\
$\mathrm{NADP}$ & 0.1 & 340 & 0 \\
Ferricyanide & 0.5 & 420 & 21.2 \\
2,6-Dichlorophenol- & & & \\
$\quad$ indophenol & 0.04 & 600 & 20.4 \\
Nitro blue tetrazolium & 0.1 & 540 & 6.0 \\
Cytochrome $c$ & 0.1 & 550 & 0 \\
\hline
\end{tabular}


When the compounds listed in Table VI were examined as electron acceptor for the oxidation of xanthine, the activity was highest with $\mathrm{O}_{2}$, and also ferricyanide or 2,6-dichlorophenolindophenol served as electron acceptor, but slight activity was noted with NAD, NADP, and cytochrome $c$.

$\mathrm{Km}$ values obtained with Lineweaver-Burk plots of the activities were $0.11,0.15$, and $0.3 \mathrm{~mm}$ for xanthine, hypoxanthine, and guanine, respectively.

\section{Stoichiometry of the reaction}

The stoichiometries for the reaction were shown in Table VII. During the oxidation of xanthine, hypoxanthine, or guanine, almost stoichiometric amounts of $\mathrm{O}_{2}$ consumption and $\mathrm{H}_{2} \mathrm{O}_{2}$ generation were observed.

TABLE VII. StOICHIOMETRY OF THE ReACtion

(A) $\mathrm{O}_{2}$ consumption was measured manometrically at $37^{\circ} \mathrm{C}$ for 30 min with a Warburg apparatus. The experiments were performed in mixture $(2.0 \mathrm{ml})$ con-

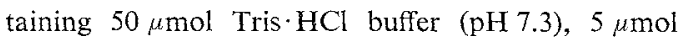
4-aminoantipyrine, $5 \mu \mathrm{mol}$ phenol, 2.5 units of peroxidase, 2.6 units of XOD (side arm), and substrates listed at the concentration.

(B) $\mathrm{H}_{2} \mathrm{O}_{2}$ generation was measured by using substrates listed instead of xanthine in the assay method II involved 0.92 unit of $\mathrm{XOD}$.

\begin{tabular}{lcc}
\multicolumn{1}{c}{ Substrate } & $\begin{array}{c}\text { Substrate added } \\
(\mu \mathrm{mol})\end{array}$ & $\begin{array}{c}\mathrm{O}_{2} \text { consumed } \\
(\mu \mathrm{mol})\end{array}$ \\
\hline Xanthine & 1.25 & 1.22 \\
& 2.50 & 2.25 \\
Hypoxanthine & 1.25 & 2.17 \\
& 2.50 & 4.65 \\
\hline B & & \\
\hline Substrate & Substrate added & $\mathrm{H}_{2} \mathrm{O}_{2}$ generated \\
& $(\mu \mathrm{mol})$ & $(\mu$ mol $)$ \\
\hline Xanthine & 0.15 & 0.15 \\
Hypoxanthine & 0.15 & 0.27 \\
Guanine & 0.15 & 0.14 \\
\hline
\end{tabular}

\section{DISCUSSION}

We found the xanthine oxidase activity in Enterobacter cloacae KY3074 among the bacteria grown in a medium containing xanthine.

The crude extract of the other bacteria grown on the xanthine media indicated a weak xanthine oxidase activity, when uric acid production from xanthine was measured with $\mathrm{O}_{2}$ as electron acceptor (assay method I). Woolfolk and Downard has also reported that some bacteria indicate a weak xanthine oxidase activity as our experiments. ${ }^{4}$

Although the purine catabolism of E. cloacae KY3074 is easily inferred from the reports that some of Enterobacteriaceae can utilize purine bases as a source of carbon and nitrogen, ${ }^{17}$ ) the apparent enzyme activity was only observed in this strain among Enterobacteriaceae. Furthermore, this strain grew in a medium containing uric acid and produced uricase, as previously reported. ${ }^{18,}$

Xanthine oxidase was induced in the bacterial cells by guanine, xanthine, and especially hypoxanthine, all of which were substrate of the enzyme. The effective enzyme induction by hypoxanthine may be related to the two step oxidation of the compound uptaken from the surrounding medium by the enzyme. The enzyme induction by guanine is not clear as to whether this is done by guanine itself or xanthine produced from guanine by guanine deaminase or by both of them. Guanosine and GMP having a moderately higher solubility than guanine induced the enzyme as effectively as hypoxanthine. This result may suggest that guanine can induce the enzyme essentially as well as hypoxanthine can, but the very low solubility prevents the uptake of guanine into the cells and effective enzyme induction by the compound. Because adenine or adenosine slightly induced the enzyme, adenine deaminase activity or adenosine deaminase activity may be very weak or does not exist in this strain.

Enterobacter xanthine oxidase was usually stable in a state of the crude extract and during purification processes. The purified enzyme preparation had a few minor protein bands in polyacrylamide gel electrophoresis, but in SDS-electrophoresis almost single protein band was obtained. The minor protein bands may be due to decomposition or coagulation of the native enzyme during the purification processes as reported for Arthrobacter 
enzyme. ${ }^{9)}$

The enzyme may be a dimer consisted of identical subunit with a molecular weight of 69,000 . The molecular weight of the enzyme was almost identical with Streptomyces xanthine dehydrogenase, ${ }^{8 !}$ somewhat smaller than Arthrobacter xanthine oxidase, ${ }^{9}$ and was about a half or one-third of those of xanthine oxidizing enzymes from other sources. ${ }^{2,5 \sim 7,19 \sim 22)}$

The isoelectric point was at $\mathrm{pH} 3.8$, and was lower than those of other xanthine oxidizing enzymes. ${ }^{8)}$

The spectrum of this enzyme was similar to those of some xanthine oxidizing enzymes. ${ }^{6,8,9,22)}$ The spectrum of Enterobacter enzyme included the peak at 280 and $450 \mathrm{~nm}$, and the shoulder at 425 and $473 \mathrm{~nm}$. The peak at $450 \mathrm{~nm}$ and shoulders were reduced with sodium hydrosulfite. The spectral characteristics suggest that Enterobacter enzyme is flavoprotein containing non-hem iron as other xanthine oxidizing enzymes.

The enzyme had a relatively wide substrate specificity for various purine bases. The enzyme oxidized xanthine, hypoxanthine, and also guanine at considerable rates. During the oxidation of guanine the release of ammonia due to guanine deaminase was not detected. The determination of ammonia was performed by measuring the reductive amination of $\alpha$-ketoglutarate catalized by glutamate dehydrogenase. Therefore, the XOD oxidizes guanine and the oxidation product appears to 8-hydroxyguanine same as that of xanthine dehydrogenase from Streptomyces. $\left.{ }^{8}\right)$

The xanthine dehydrogenase from Streptomyces can oxidize guanine, but the enzyme has a higher affinity for guanine than for hypoxanthine and xanthine in contrast to Enterobacter enzyme.

The $K m$ value for xanthine was higher than those of milk enzyme and other related enzymes, and was similar to those of Arthorobacter enzyme. ${ }^{9 \text { ) }}$

The enzyme oxidized benzaldehyde same as milk enzyme, ${ }^{23}$ ) but did not oxidize NADH.

In the Enterobacter enzyme, $\mathrm{O}_{2}$, ferricyanide, and 2,6-dichlorophenolindophenol served as an electron acceptor. Of these electron acceptors, $\mathrm{O}_{2}$ was the most effective electron acceptor, and this was very different from other xanthine oxidizing enzymes. ${ }^{7,8,23}$ Although the xanthine oxidase has been reported from Arthrobacter by Woolfolk and Downard ${ }^{9}$ $\mathrm{O}_{2}$ is not the most effective electron acceptor, but ferricyanide is most effective for the enzyme. Furthermore, also in milk xanthine oxidase ferricyanide is most effective. ${ }^{22}$ Milk enzyme and Arthrobacter enzyme is similar to aldehyde oxidase in the electron acceptor specificity. In these enzymes, $\mathrm{O}_{2}$ shows only about $80 \%$ activity of ferricyanide as electron acceptor. ${ }^{23)}$

From these results, we concluded that the Enterobacter enzyme is a new type of xanthine oxidase given the highest activity toward molecular oxygen.

\section{REFERENCES}

1) W. H. Bradshaw and H. A. Barker, J. Biol. Chem., 235, 3620 (1960).

2) S. T. Smith, K. V. Rajagopalan and P. Handler, J. Biol. Chem., 242, 4108 (1967).

3) C.A. Woolfolk, B.S. Woolfolk and H.R. Whiteley J. Biol. Chem., 245, 3167 (1970).

4) C. A. Woolfolk and J.S. Downard, J. Bacteriol., 130, 1175 (1977).

5) I. L. Sin, Biochim. Biophys. Acta, 410, 12 (1975).

6) E. S. Lyon and R. H. Garrett, J. Biol. Chem., 253, 2604 (1978).

7) T. Sakai and H. K. Jun, Agric. Biol. Chem., 43, 753 (1979).

8) T. Ohe and Y.Watanabe, J. Biochem., 86, 45 (1979).

9) C. A. Woolfolk and J. S. Downard, J. Bacteriol., 135, 422 (1978).

10) J. L. Mahler, Anal. Biochem., 38, 65 (1970).

11) C.C. Allain, L.S. Poon, C.S.G. Chan, W. Richmond and C. Fu, Clin. Chem., 20, 470 (1974).

12) O. H. Lowry, N. J. Rosebrough, A. L. Farr and R. J. Randall, J. Biol. Chem., 193, 265 (1951).

13) B. J. Davis, Ann. N. Y. Acad. Sci., 121, 404 (1964).

14) K. Weber and M. Osborn, J. Biol. Chem., 244, 4406 (1969).

15) P. Andrews, Biochem. J., 91, 222 (1964).

16) O. Vesterberg and H. Svensson, Acta Chem. Scand., 20, 820 (1966).

17) G. D. Vogels and C. V. D. Drift, Bacteriol. Rev., 40, 403 (1976).

18) Y. Machida and T. Nakanishi, Agric. Biol. Chem., 44, 2811 (1980). 
19) R. Y. Andres, Eur. J. Biochem., 62, 591 (1976).

20) N. J. Lewis, P. Hurt, H. M. Sealy-Lewis and C. Schazzocchio, Eur. J. Biochem., 91, 311 (1978).

21) K. V. Rajagopalan and P. Handler, J. Biol. Chem., 242, 4079 (1967).
22) V. Massey, P. E. Brumby, H. Komai and G. Palmer, J. Biol. Chem., 244, 1682 (1969).

23) R. C. Bray, "The Enzymes," Vol. XII, ed. by P. D. Boyer, Third Edition, Academic Press Inc., New York, N. Y., 1975, p. 299. 